\title{
ART IN MEDICINE: A RETROSPECTIVE ON THE ANATOMICAL DRAWINGS OF CHARLES BELL
}

\author{
Lucy Dewar ${ }^{1}$ and Andreas K. Demetriades ${ }^{2}$ \\ ${ }^{1}$ Ninewells Hospital, Dundee, Scotland, UK; \\ ${ }^{2}$ Western General Hospital, Edinburgh, Scotland, UK
}

\begin{abstract}
SUMMARY - Perhaps best known for his discovery of the eponymous syndrome 'Bell's Palsy', Charles Bell (1774-1842) made significant contributions to neuroscience, medical education and philosophy. Our aim was to examine his neuroanatomical drawings in the context of the era in which they were produced and their influence on future scholars. Emphasis is placed on analysing the artistic techniques employed and Bell's unique manner of conveying both structure and function. The images discussed include those featured in his book entitled The Anatomy of the Brain: Explained in a Series of Engravings. These images can be viewed in parallel with his writing on the anatomy of the brain, in which he describes the usual manner of demonstrating neuroanatomy as 'dull' and 'unmeaning'. His mastery of artistic technique complements his insightful descriptions of this prodigiously complex organ. The result is a more engaging account of neuroanatomy and an impressive display of his skill as an artist, anatomist and physician. Examining these expressive portrait-like diagrams provides greater insight into the mind of the pioneer of modern neuroscience.
\end{abstract}

Key words: Charles Bell; Art; Anatomy, illustration; Neuroanatomy

\section{Introduction:}

\section{A Brief History of Anatomical Illustration}

For as long as there has been information to share, imagery has been a means of communicating it. Pictograms outdate written language as a form of expression and means of preserving information for future generations. The far-reaching extent of this is evidenced by cave paintings that were produced in the Stone Age. Ancient man would use illustration to demonstrate basic animal biology and efficient hunting techniques ${ }^{1}$. Even with the emergence of text, images often are a far more elegant means of conveying meaning in some disciplines. Medicine has proven to be one of these fields and the history of medicine is

Correspondence to: Andreas K. Demetriades, FRCSEd, Consultant Neurosurgeon, Western General Hospital, Crewe Road, Edinburgh EH4 2XU, Scotland, UK

E-mail: andreas.demetriades@gmail.com

Received October 16, 2019, accepted November 20, 2019 densely intertwined with the creation of visual imagery. There has always been a parallel between art and medicine. The artwork of antiquity provides a valuable account of the salient ideas of the time and of scientific discoveries in rapidly developing societies.

Dissection was first initiated in ancient Alexandria; many credit the Greek physician Herophilus for this ${ }^{2}$. The discoveries of Herophilus loosely outlined the functions of major organs and birthed the ideas of anatomy and physiology. He was the first to describe the brain as the organ responsible for thought and intelligence; it was previously thought to be the heart. Illustration would have been the means of publishing and sharing this information ${ }^{3}$. Unfortunately, all this work was lost with time and the destruction of the great library of Alexandria. Only through the accounts of Galen and subsequent physicians is anything known about that time ${ }^{4}$.

To move further forward in this narrative, during the Renaissance, there was a movement toward artists 
seeking to create more realistic studies of the human form ${ }^{5}$. Observing dissection was an excellent way of understanding muscular structure ${ }^{6}$. Michelangelo and Raphael were said to have studied cadavers ${ }^{1,7}$. It became commonplace for artists and scientists to collaborate, physicians of this period began to see the value of these drawings which could capture structures with beauty and clarity. Physicians and anatomists would hire artists to illustrate structures and concepts, although it was often difficult to persuade artists to work with cadavers, given that the embalming process was still primitive during this period. Additionally, without sufficient knowledge of anatomy, artists were liable to misrepresent structures or overlook their importance ${ }^{8}$.

As time went on, more systematic outlines of anatomy were published for the purposes of medical education. In 1543, Andreas Vesalius, a Belgian physician and anatomist, was believed to have created the first atlas of human anatomy entitled De Humani Corporis Fabrica ${ }^{9}$. This systematic series of drawings was intended for use as an educational tool. Vesalius utilised artists to create this series of drawings, he taught these artists using his own sketches. The cadavers are shown conforming to classical notions of beauty and proportion. They are often in dramatic poses and shown as though animate to reflect spiritual ideas of the time ${ }^{10}$.

Nonetheless, there were few anatomists in this period that created their own drawings.

Charles Bell was one such physician and is an interesting part of the continuing narrative of art in medicine.

\section{Research Methods}

Much of the source material for this project was obtained from online archives of the work of Charles Bell. These archives include the Wellcome Library (https://wellcomecollection.org/) and the Medical Heritage Library (https://archive.org/details/medicalheritagelibrary).

Secondary source material from biographers of Bell was obtained via literature search using PubMed. The search terms used were 'Charles Bell 1774-1842' and 'Neuroanatomical drawings'. Some of the images mentioned are available to view in the Surgeons $\mathrm{Mu}^{-}$ seum in Edinburgh and the accompanying information was utilised when writing this project.

\section{Biography of Charles Bell}

\section{Early life and education}

Given his success and numerous medical discoveries, the life of Charles Bell has been well chronicled by historians. His early life is worth examining as a source of influence in his work and art. He was born in Edinburgh in 1774 as the youngest child of William and Margaret Bell. After the passing of his father, who was 70 years old at the time of his youngest son's birth, Bell was raised largely by his mother after the age of 5 . His mother, who was well educated and artistically inclined, was eager to cultivate his early interest in the arts $^{11}$. The young Bell received tutelage under the Scottish painter David Allen, who may have provided early influence in dictating Bell's artistic style ${ }^{12}$. Allen was well known for his portraiture works and for capturing domestic scenes in his paintings ${ }^{13}$. He encouraged Bell to study the works of acclaimed artists and work with multiple mediums including paint and wax modelling. Bell did not receive much formal education, spending only 4 years at school but claimed to have learned a lot from his older siblings and from self-study. Bell went on to study at Edinburgh Medical School. He was in the class of his older brother John Bell who was an eminent surgeon and had a role in medical education during this period.

\section{Studying at Edinburgh Medical School under John Bell}

John Bell was a prolific medical illustrator and innovative surgeon in his own right. He published an immense quantity of work and was labelled by some as the 'father of modern surgical anatomy ${ }^{14}$. He was among the first to advocate thorough anatomy teaching as essential to surgery training and believed that using illustrated diagrams as an educational tool was invaluable. John Bell was also one of the few to produce his own anatomical drawings, which were meticulously drawn and widely used. This was the time when there were insufficient bodies available for dissection and some of the bodies had been exhumed and therefore were decaying or in poor condition ${ }^{6}$.

John Bell was very influential to his younger brother, who would go on to become his apprentice and subsequently his co-author. They worked together on the Anatomy of the Human Body, while Charles was still a 
medical student. While John created a greater volume of drawings, he is perhaps less well known than his younger brother is. Perhaps this is, in part, due to Charles Bell working in a more diverse selection of mediums and leaving behind several distinctive oil paintings $s^{15}$. Charles Bell had more of a focus on illustrating the nervous system and was arguably a more skilled artist. There are subtle differences in their style of capturing their subjects. John Bell's drawings were simpler and more overtly diagrammatic, whereas his younger brother's work was often more expressive, alluding to more than just structure ${ }^{15}$.

\section{Work in Edinburgh and move to London}

Charles graduated from Medical School in 1798 and was admitted to the Royal College of Surgeons. He worked as a surgeon in Edinburgh Royal Infirmary while he continued to collaborate with his brother to publish the third and fourth volumes of the Anatomy of the Human Body in 1802 and 1803. During this period, animosity developed between John Bell and medical administrators at the hospital. As a result, both he and Charles were prevented from operating in the infirmary at that time. Therefore, Charles was advised that to advance his career it would be best if he moved to London, which he did in $1804^{12}$. Even after relocating, he still had strong links to Edinburgh in the form of on-going communications with another of brothers, George Bell, who he continually looked upon as a source of guidance. These letters are archived in the Royal College of Surgeons in London and provide insight into the ambitions of the youngest Bell brother and details of his life in London ${ }^{16}$.

\section{Important Works of Charles Bell}

\section{Essays on the anatomy of expression in painting}

Upon initially moving to London, Bell published his manuscript Essays on the Anatomy of Expression in Paintings, which was a treatise designed to advise artists and anatomists alike on the structures underpinning human facial expression ${ }^{17}$. Nonetheless, the text was not only a description of anatomy; Bell used the manuscript to subtly espouse some of his philosophical views and his belief that "expression is to passion what language is to thought" ${ }^{\prime 18}$. Additionally, his views on natural philosophy become apparent. He describes the nature and complexity of facial expression as evidence of a god-like creator. The piece was extensively researched, he observed the facial expressions of infants and noted the expressive facial muscles in humans that were absent in other species, speculating their role in communication and forming relationships (Fig. 1). This unique work was well received and later even praised by Darwin when he was examining human and animal expression, even though he did not necessarily infer the same religious conclusions ${ }^{19}$.

Many of the drawings were produced by Bell himself, although he did hire artists to produce some images. There is a combination of meticulous anatomical diagrams and expressive free form sketches. Bell puts across that a painter must understand the character of a subject to fully capture his expression, that he must borrow from the physician and observe when imagination will not suffice ${ }^{18}$.

For example, Figure 2 shows a character that Bell described as 'the maniac' or the 'mad man'. Bell says: "The error into which a painter would naturally fall, is to represent this expression by the swelling features of passion and the frowning eyebrow; but this would only convey the idea of passion, not of madness. I have observed (contrary to my expectation) that there was not that energy, that knitting of the brows, that indignant brooding and thoughtfulness in the face of madmen. There is a vacancy in their laugh, and a want of meaning in their ferociousness" ${ }^{17}$. Bell demonstrates that he is keenly attuned to the subtleties of human emotion and expression, speaking from the rare position of being both a talented artist and observant physician. This kind of insight is what makes it such an influential text and allows him to capture these subjects with such accuracy and depth.

\section{Military Paintings}

Bell continued to find success in London, he taught anatomy and surgery from his home in Leicester Street. His lectures were well attended by both medical students and artists. When he had the funds to do so, he purchased a share of the Great Windmill Street School of Anatomy in 1812, where he subsequently based his lectures. In 1814, he was admitted to the Royal College of Surgeons in London, which allowed him to practice as a surgeon in Middlesex Hospital ${ }^{20}$.

During this period, Bell also worked as a military surgeon and produced an emotive series of works de- 
picting the gunshot wounds and other mortal injuries sustained by soldiers at the Battle of Waterloo. Some of these oil paintings are still on display in the Surgeons Museum in Edinburgh. They mostly showcase the horrors of battle; Bell captured the often mortal gunshot wounds of his patients with raw detail. They serve not only as a surgical guide but provide a distinctive account of the Napoleonic wars ${ }^{21}$. What I find particularly notable is the detail in their facial expressions and the care taken to capture the emotions of these soldiers. Bell emphasises that their personal suffering is to take equal focus to the nature of their wounds. Bell had rather limited success in treating these patients, and this sense of hopelessness is clearly reflected in their faces (Figs. 3 and 4).

\section{Contributions to neurophysiology: a new anatomy of the brain}

Charles Bell is perhaps best known for his contributions to neurology, as this was his primary field of interest. During this period, there were already accounts of the structures of the brain and its primary functions; however, many structures were still poorly defined $^{11}$. Bell's work altered the accepted view of the human nervous system; he had a role in distinguishing the functions of motor and sensory nerves. He is perhaps better known for describing the eponymous syndrome Bell's palsy (facial nerve dysfunction) ${ }^{11}$.

His passion for the subject is apparent in his book A Nerw Anatomy of the Brain, which he initially only distributed to friends. This piece is mainly for educational purposes and does highlight some of Bell's own discoveries, such as the functions of the cerebrum and the cerebellum. Additionally, we can understand some of Bell's own views on this organ, which he dedicated so much of his career to. He declares that "the dull unmeaning manner which is in use of demonstrating the brain, may authorise any novelty in the manner of treating the subject"22. It alters the perspective of the reader when learning about such a densely complex organ from a writer who speaks of the structures with such familiarity and almost fondness.

\section{A series of engravings and techniques employed}

In my opinion, Bell's marrying of artistic and surgical expertise is never more evident than in The Anatomy of the Brain: Explained in a Series of Engravings. This was a series of stipple engraved plates he produced to demonstrate the anatomy of the brain ${ }^{12}$. Stippling was a commonly used technique during this period and involved engraving many small lines and dots onto a printing plate to produce different tones. Many of the plates are hand coloured and are each accompanied by an explanatory text. Bell puts forward that illustrations are an excellent way to learn about these structures, which are often too delicate to be observed via dissection and are so distinct from other bodily tissue.

These images have a phenomenal amount of detail and clarity while still preserving an element of artistry. Figure 5 shows the first plate in the series, which is a superior view of the brain dissected. The image attempts to showcase the subject's humanity and give a sense of their character by including the detail in the face. The posture of the subject gives the viewer a sense that the figure is resting, leading them to think of them as a person as opposed to just an organ. It is almost difficult to discern if this is a portrait or a diagram. These added details provide the human context for the surgical procedures that they are designed to inform. Often there is a humanity lacking from diagrams that put out of focus what the surgeon hopes to achieve in treating a patient.

Bell also demonstrates a cognisance of the seemingly contradictory aims of accurate anatomical illustration and artistic expression. An anatomical diagram aims to accurately capture how the structure should appear in life. However, some aspects can be altered to make them easier to view and understand. For example, overlapping structures are often conveyed as though adjacent so that nothing is obscured. Additionally, any features that are unique to the subject are frequently altered for a more accurate representation of the norm. This is contrary to the aspiration of many artists, who would deem capturing the individuality of the subject as the primary focus of the piece ${ }^{23}$. Bell often balances these priorities differently, sometimes leaning toward an idealised anatomical depiction and at other times seeking a portrayal of the individual, such as in his military paintings, for example.

\section{Return to Edinburgh and the Legacy of Charles Bell}

In 1836, remarking that London was a place to live in and not one to die in, Bell accepted the position of Chair of Surgery at the University of Edinburgh and 


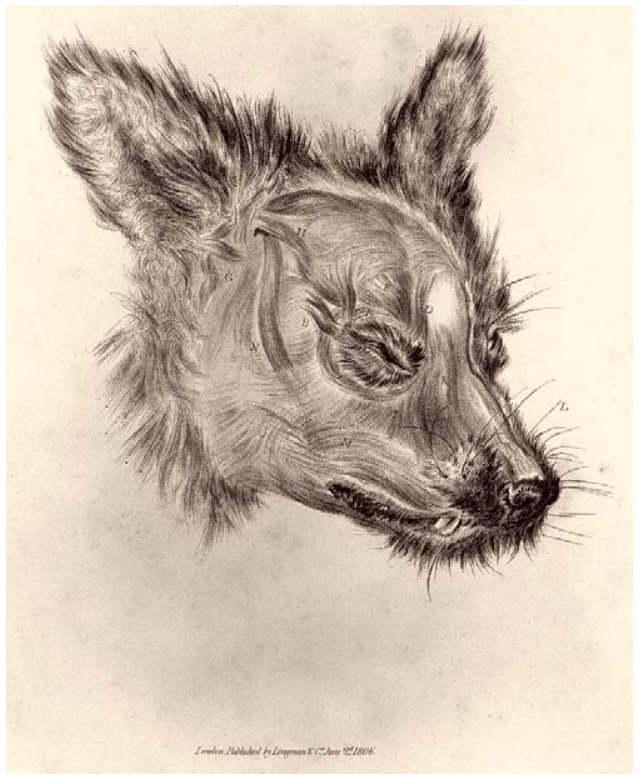

Fig. 1. The head of a dog dissected - from Essays on the Anatomy of Expression

Credit: Wellcome Library, London. Wellcome Images (images@wellcome.ac.uk).

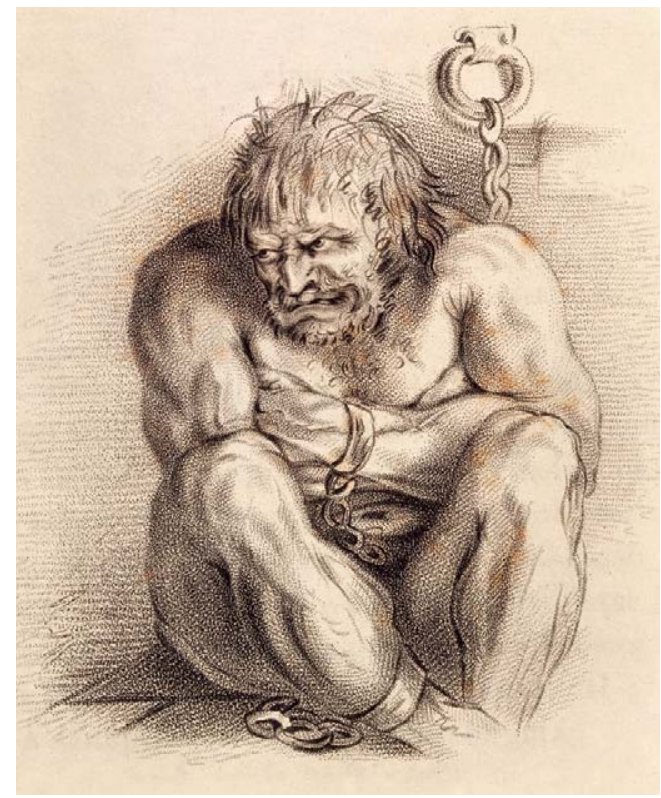

Fig. 2. The mad man - from Essays on the Anatomy of Expression

Credit: Wellcome Library, London. Wellcome Images (images@wellcome.ac.uk).

returned to his place of birth ${ }^{11}$. During his lifetime, Bell amassed a large collection of anatomical drawings and surgical specimens. Much of this collection now

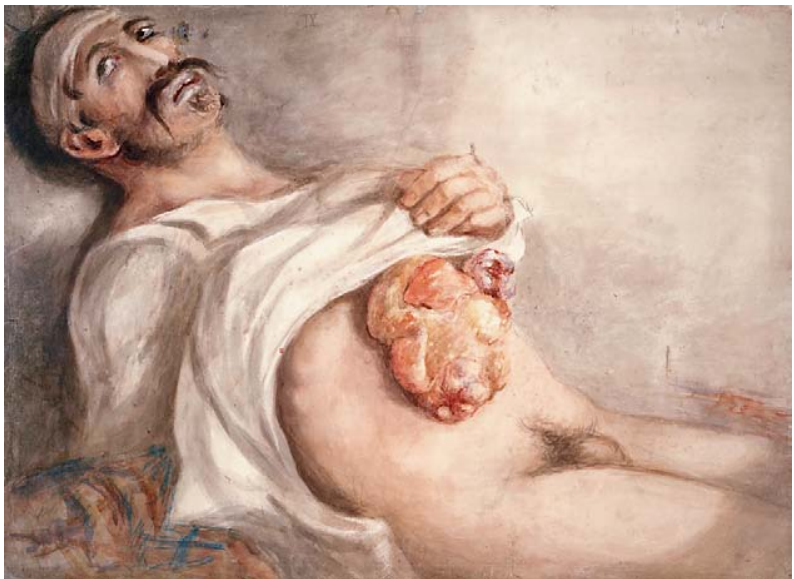

Fig. 3. Sabre wound to abdomen. Credit: Wellcome Library, London. Wellcome Images (images@wellcome. ac.uk).

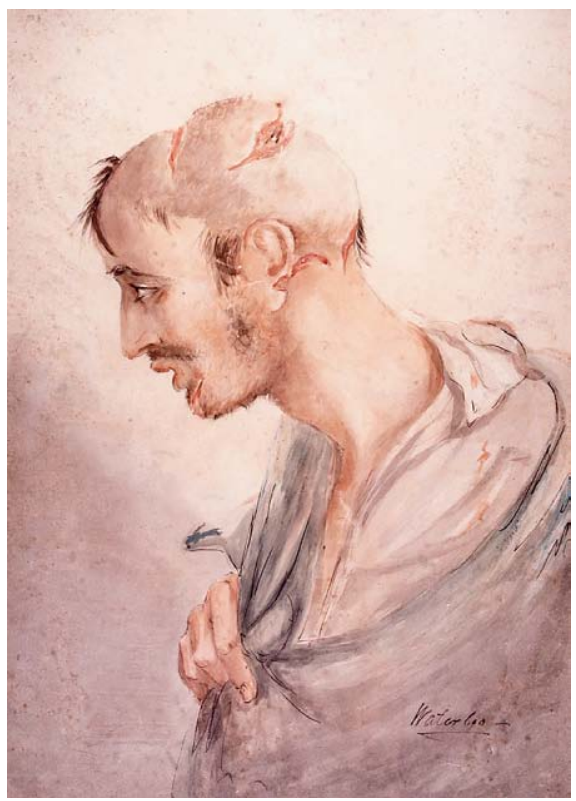

Fig. 4. Soldier suffering from head and facial injuries. Credit: Wellcome Library, London. Wellcome Images (images@wellcome.ac.uk).

belongs to the Royal College of Surgeons in Edinburgh.

There is a reason why Bell's life is so well documented by historians. Not only did he have a huge impact on neurophysiology but also his talents as a writer and artist have produced an influential body of work. One historian remarks that he "did enough to lay the foundations of a dozen reputations but he did too much too complete one" ${ }^{20}$. This is perhaps a harsh as- 


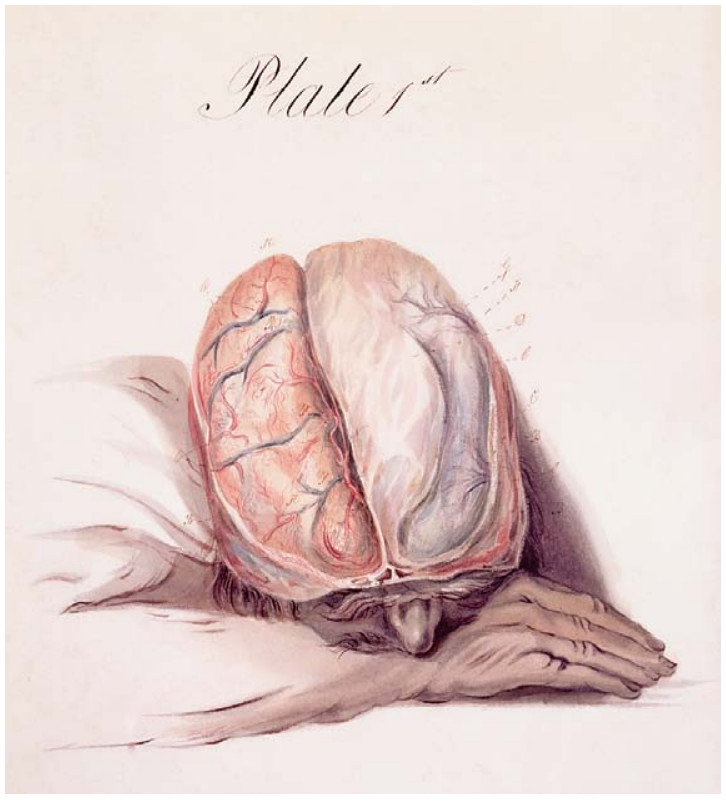

Fig. 5. View of the brain dissected - from The Anatomy of the Brain: Explained in a Series of Engravings. Credit: Wellcome Library, London. Wellcome Images (images@wellcome.ac.uk).

sessment but has been the fate of many polymaths. Nonetheless, Bell can be remembered for cementing the role of illustration in medical education and influencing future physicians and artists alike.

Illustration is still a teaching method used to this day despite the advent of photography. In the future, graphic design and the production of 3D images may have increasing value in teaching situations ${ }^{24}$. Indeed, medical illustration will need to be a term to encompass design of holograms and virtual reality simulations.

\section{Conclusion}

Art will always have a role in medicine. Following the close yet ever changing relationship of these subjects through time highlights many influential figures in history. Charles Bell, being one such person, can be remembered for his unique and multifaceted view on neuroanatomy and passion for teaching. His distinctive artistic style is what makes his art work memorable and provokes empathy from the viewer toward the subject. Few others could aptly capture the brain in a way that requires an anatomist's knowledge of structure and an artist's tools of expression.

\section{References}

1. Hajar R. Medical illustration: art in medical education. Heart Views. Wolters Kluwer - Medknow Publications; 2011;12(2): 83-91.

2. Bay NS-Y, Bay B-H. Greek anatomist herophilus: the father of anatomy. Anat Cell Biol. 2010; 43(4):280-3.

3. Tomey MI, Komotar RJ, Mocco J. Herophilus, Erasistratus, Aretaeus, and Galen: ancient roots of the Bell-Magendie Law. Neurosurg Focus. 2007; 23(1):E12.

4. Hajar R. History of Medicine: Past Glories - The Great Library of Alexandria. 2000;1(7):278-82.

5. Paluzzi A, Belli A, Bain P, Viva L. Brain “imaging” in the Renaissance. J R Soc Med. 2007;100(12):540-3.

6. Ghosh SK. Human cadaveric dissection: a historical account from ancient Greece to the modern era. Anat Cell Biol. 2015; 48(3):153-69.

7. Strauss RM, Marzo-Ortega H. Michelangelo and medicine. J R Soc Med. 2002;95(10):514-5.

8. Loechel WE. The history of medical illustration. Bull Med Libr Assoc. 1960;48(2):168-71.

9. Mesquita ET, Souza Júnior CV de, Ferreira TR. Andreas Vesalius 500 years - a Renaissance that revolutionized cardiovascular knowledge. Rev Bras Cir Cardiovasc. 2015;30(2):260-5.

10. Ganseman Y, Broos P. Leonardo da Vinci and Andreas Vesalius; the shoulder girdle and the spine, a comparison. Acta Chir Belg. 2008;108(4):477-83.

11. Tubbs RS, Riech S, Verma K, Mortazavi MM, Loukas M, Benninger B, et al. Sir Charles Bell (1774-1842) and his contributions to early neurosurgery. Child Nerv Syst. 2012;28(3):331-5.

12. Aminoff MJ. Sir Charles Bell: His Life, Art, Neurological Concepts, and Controversial Legacy. New York: Oxford University Press; 2017.

13. David Allan (1744-1796) | Art UK [Internet]. Available from: https://www.artuk.org/discover/artists/allan-david-17441796

14. Kaufman MH. John Bell (1763-1820), the "father" of surgical anatomy. J Med Biogr. 2005;13(2):73-81.

15. Gardner-Thorpe C. John Bell (1763-1820): brother artist and anatomist. Prog Brain Res. 2013;203:163-83.

16. Royal College of Physicians London. Letters of Sir Charles Bell selected from his correspondence with his brother George Joseph Bell. Royal College of Physicians of London. London: John Murray; 1870. [Available from: https://archive.org/details/b28034302]

17. Bell C. Essays on the Anatomy of Expression In Painting. London: Longman, Hurst, Rees, and Orme, Paternoster-Row; 1806.

18. Charles Bell. The Anatomy and Philosophy of Expression. London: John Murray; 1844; p. 280.

19. Loudon ISL. Sir Charles Bell and the anatomy of expression. $\mathrm{Br}$ Med J. 1982;285(6357):1794-6.

20. van Gijn J. Charles Bell (1774-1842). J Neurol. 2011;258 (6):1189-90. 
21. Crumplin MKH, Starling PH. Royal College of Surgeons of Edinburgh. A surgical artist at war: the paintings and sketches of Sir Charles Bell, 1809-1815. Edinburgh: Royal College of Surgeons of Edinburgh; 2005, p. 96.

22. Bell C, Shaw A. Reprint of the "Idea of a New Anatomy of the Brain”, with Letters, \&c. J Anat Physiol. 1868;3(Pt 1):147-82.
23. Neher A. Classicism and Sir Charles Bell's engravings of the nerves. Hektoen Int. 2017. Available from: http://hekint.org/ classicism-sir-charles-bells-engravings-nerves/

24. Bell LT, Evans DJ. Art, anatomy, and medicine: is there a place for art in medical education? Anat Sci Educ. 2014;7(5): 370-8.

Sažetak

\section{UMJETNOST U MEDICINI: RETROSPEKTIVA ANATOMSKIH CRTEŽA CHARLESA BELLA}

\section{Dewar i A. K. Demetriades}

Iako je možda najpoznatiji po otkriću sindroma koji je po njemu nazvan Bellova paraliza, nemjerljiv je doprinos Charlesa Bella (1774.-1842.) neuroznanosti, medicinskoj izobrazbi i filozofiji. Cilj je bio istražiti neuroanatomske crteže u kontekstu vremena u kojem su nastali te njihov utjecaj na buduće znanstvenike. Naglasak je na analizi primijenjenih umjetničkih tehnika te na Bellovu jedinstvenom načinu prikazivanja strukture i funkcije. Raspravlja se o slikama koje se nalaze u njegovoj knjizi "Anatomija mozga: objašnjenje kroz niz gravura” (The Anatomy of the Brain: Explained in a Series of Engravings). Ove slike mogu se promatrati usporedno s njegovim tekstovima o anatomiji mozga u kojima on opisuje uobičajeni način prikazivanja neuroanatomije kao "dosadne" i "besmislene". Njegova majstorska umjetnička tehnika dopunjava njegove pronicave opise ovoga silno složenoga organa. Rezultat je znatno privlačniji pogled na neuroanatomiju i dojmljiv prikaz njegove vještine kao umjetnika, anatoma i liječnika. Izučavanje ovih izražajnih dijagrama nalik portretima omogućava bolji uvid u um ovoga pionira suvremene neuroznanosti.

Ključne riječi: Charles Bell; Umjetnost; Anatomija, ilustracija; Neuroanatomija 